Three Laws of Nature 
This page intentionally left blank 


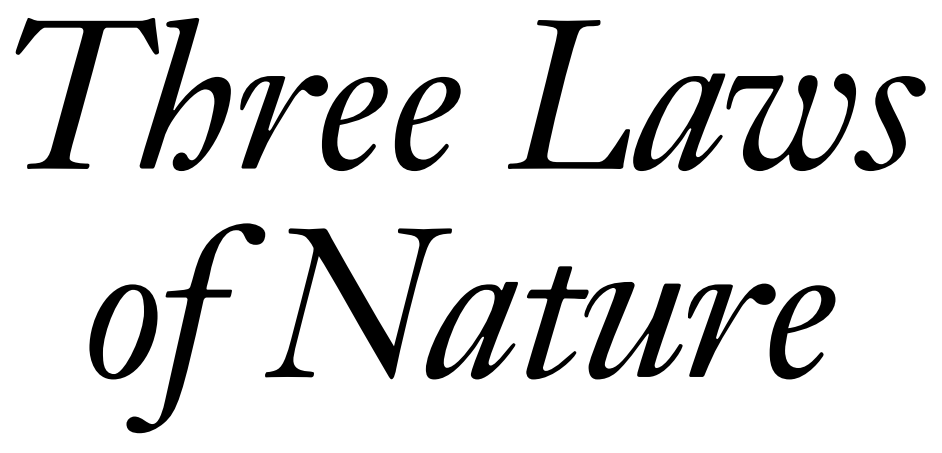

A Little Book on Thermodynamics

\section{R. Stephen Berry}

Yale UNIVERSITY PRESS

New Haven \& London 
Published with assistance from the foundation established in memory of Philip Hamilton McMillan of the Class of 1894, Yale College.

\section{Copyright @ 2019 by R. Stephen Berry.}

All rights reserved.

This book may not be reproduced, in whole or in part, including illustrations, in any form (beyond that copying permitted by Sections 107 and 108 of the U.S. Copyright Law and except by reviewers for the public press), without written permission from the publishers.

Yale University Press books may be purchased in quantity for educational, business, or promotional use. For information, please e-mail sales.press@yale.edu (U.S. office) or sales@yaleup.co.uk (U.K. office).

Set in Janson Roman type by Integrated Publishing Solutions. Printed in the United States of America.

ISBN 978-0-300-23878-5 (hardcover : alk. paper) Library of Congress Control Number: 2018954948

A catalogue record for this book is available from the British Library.

This paper meets the requirements of ANSI/NISO Z39.48-1992 (Permanence of Paper). 